\title{
Determinants for the success of regional ICT ventures: a close examination of South Korea
}

Eunil Park' ${ }^{1}$ Ki Joon Kim² ${ }^{*}$, Sang Jib Kwon ${ }^{3}$, Jay Y. Ohm ${ }^{4 *}$, Angel P. del Pobil ${ }^{5,6}$ and Kyeongsik Yoo ${ }^{4,7}$

\begin{abstract}
Background: This study identifies the key motivational factors in enhancing economic performance and increasing new job opportunities for information and communication technology ventures (ICTVs) in South Korea and examines their potential causal relationships through structural equation modeling analysis on data collected from over 200 ICTVs located in Daedeok Innopolis.

Results: The results indicate that the economic performance of ICTVs is determined mainly by government support, innovation effort, and private equity and support. Government support and innovation effort are also positively associated with new job opportunities.

Conclusions: The theoretical, industrial implications of the key findings, and recommendations for the Korean government are discussed.

Keywords: Innovation effort, Government support, Economic performance, Job opportunity, ICT venture, Daedeok Innopolis
\end{abstract}

\section{Background}

Over the past few decades, South Korea has emerged as a leader in information and communication technology (ICT), while related businesses and ventures have grown dramatically in both quality and quantity. Extensive research on the key motivational factors for the rapid economic growth has ascertained that high-quality human resources and systematic government support have played significant roles in promoting economic growth and sustainability in South Korea (Sengupta and Espana 1994; Pahlavani and Harvie 2008; Shin and Hassink 2011). The financial and political support of the government is believed to be the leading driver of nationwide research and development (R\&D) activities (Kim 1999; Yun and Lee 2013). Additionally, private equity

\footnotetext{
*Correspondence: kj.kim@cityu.edu.hk; johm@kaist.ac.kr

${ }^{2}$ Department of Media and Communication, City University of Hong

Kong, Kowloon, Hong Kong

${ }^{4}$ Korea Advanced Institute of Science and Technology (KAIST), N5 2111 ,

KAIST College Building 2, 291 Daehak-ro, Yuseong-gu, Daejeon 34141,

Republic of Korea

Full list of author information is available at the end of the article
}

and support as well as innovations such as user-centered organizational strategies (Becker and Dietz 2004) and internal research and development (Löfsten and Lindelöf 2005), have played equally critical roles in enhancing the economic capacity of ICT ventures (ICTVs), especially by increasing job opportunities (Bogliacino and Pianta 2010; Hall et al. 2008; Herzog 2011; Herzog and Leker 2010).

Given the importance of innovation effort, private equity and support, and government support, this study examines the effects of these motivational factors and their contribution to the success of ICTVs in South Korea. Focusing on the ICTVs located in Daedeok Innopolis, this study proposes a research model that explicates how the motivational factors help improve the economic performance of, and increase job opportunities at, ICTVs.

\section{Literature review and hypotheses History of Daejeon Daedeok Innopolis (DDI)}

The South Korean government established an education and research zone in Daejeon in the early 1970s to advance its national R\&D capacity. Construction of the 
infrastructure and research centers began in the mid1970s. Active collaboration among academia, industry, and research institutes began in the early 1990s upon completion of the Daedeok Research Complex in 1992; the successful hosting of the 1993 Daejeon Expo encouraged many private research centers to move to DDI. To support this collaboration, the government approved the building of a technology-oriented commercialization district providing organizations relocating in DDI with easy access to a large pool of qualified scientists and researchers as well as over $25 \%$ of the government's entire R\&D expenditure pool. In the early 2000s, legislation (e.g., the Proclamation of the Daedeok Valley, the Law of Technology Transfer Promotion, the Special Act on Developing DDI, the Special Act on Support of the Daedeok Special Research and Development Zone) was passed to support the growth of DDI (Park et al. 2011).

DDI is divided into five zones. Zone I $\left(27.2 \mathrm{~km}^{2}\right)$ and Zone $\mathrm{V}\left(4.9 \mathrm{~km}^{2}\right)$ consist of traditional science parks, including a number of research-oriented institutes. Zones II $\left(4.3 \mathrm{~km}^{3}\right)$ and Zone III $\left(3.1 \mathrm{~km}^{2}\right)$ comprise specialized industrial complexes designed to attract hightech and traditional companies, respectively. Zone IV $\left(30.2 \mathrm{~km}^{2}\right)$ is preserved as an undeveloped green belt zone for future use. These zones host five research-oriented universities (e.g., the Korea Advanced Institute of Science and Technology), 29 national research institutes, and more than 1000 ventures (including approximately 400 IT-based companies). Unlike the large South Korean conglomerates known as chaebols, most of the institutes and companies in DDI are small and medium-sized.

By 2009 , more than 45,000 DDI researchers had achieved approximately 67,000 patents and 900 technology transfers. Kim and An (2012) argue that the positive impact of the DDI ICTVs on the national economy has been produced largely through government policies and programs. They also recommend that the government improve its programs for companies in other industries, such as biotechnology and nanotechnology. Given the successes of ICTVs and their expansion in DDI, investigating the critical factors in that success is worthwhile both theoretically and practically.

After the successful launch of DDI, the South Korean government decided to create similar innovation clusters. Gwangju Innopolis, Daegu Innopolis, and Busan Innopolis were established in 2011 and became local industry and economy hubs. Gwangju Innopolis develops nextgeneration optical convergences, environmental-friendly automobiles, smart-grids, cultural content, and biomaterials; it also aims to promote South Korea's optics industry as the global cutting-edge in nanotechnology.
Daegu Innopolis specializes in medical equipment as well as smart IT, green energy, and mechatronics convergences; it fosters the convergence of various technologies as the backbone of South Korea's national industries. Finally, Busan Innopolis specializes in shipbuilding, offshore plant materials, offshore plat engineering and services, and green marine machinery (Jung and Mah 2014).

\section{Innovation effort}

Innovation effort, such as extending existing knowledge and developing new technologies, has become an essential business component in a rapidly changing society (Shan et al. 1994; Cainelli et al. 2004, 2006; Wong et al. 2005). Since Schumpeter (1961) introduced the concept of "innovation," most companies, institutes, and organizations have experimented with innovation as the growth engine for success. There are two types of innovation effort: open and closed. Chesbrough $(2003,2006)$ argued that open innovation effort is one of the most effects tools for firm success.

Much research has demonstrated the positive effects of both open and closed innovation effort on firms' R\&D (Caloghirou et al. 2004; Souitaris 2002; Amara and Landry 2005; Kim and Park 2010; Kang and Kang 2009). Open innovation effort, including user-centered and organizational innovation, leads to higher R\&D levels (Becker and Dietz 2004; Shan et al. 1994), while closed innovation also positively affects $R \& D$ (Löfsten and Lindelöf 2005; Boscherini et al. 2012; Herzog and Leker 2010). In South Korea, Lee et al. (2010) introduced various networking models to support the view that open innovation in small and medium-sized enterprises significantly improves performance. In line with their findings, this study predicts that ICTV innovation effort is positively associated with the ventures' economic performance and ability to create job opportunities:

H1 Innovation effort is positively associated with ICTVs' economic performance.

H2 Innovation effort is positively associated with job opportunities.

\section{Private equity and support}

Private equity is known to have positive effects on firms' economic performance. Wright et al. (2009) suggest that factors related to private equity such as return to investors, profitability, and productivity positively affect firms' economic and social conditions. Similarly, several studies (e.g., Wright et al. 2000, 2001; Cotter and Peck 2001; 


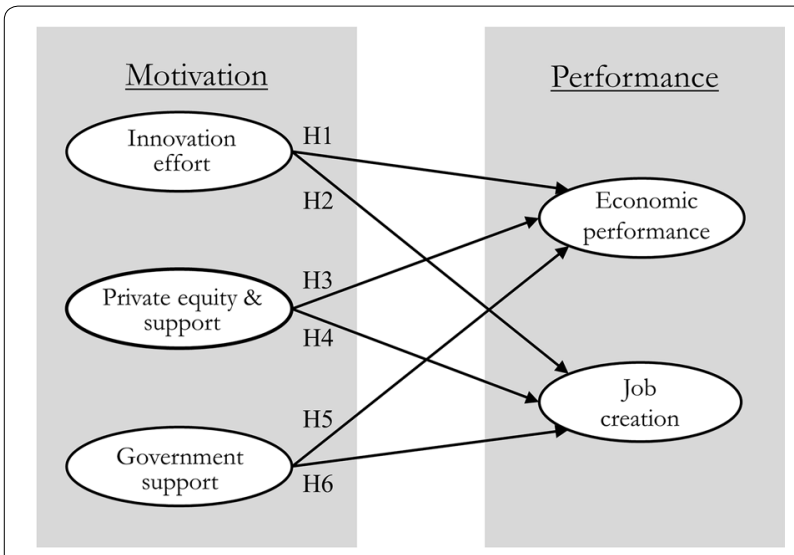

Fig. 1 The research model

Guo et al. 2011; Cornelli and Karakas 2008) have demonstrated that private equity improves firm performance, especially by allowing stockholders to monitor and engage in the firm's activities.

In addition, the positive relationship between private equity and support and employment has been frequently documented (Wood and Wright 2010). For example, Bacon et al. (2013) developed a framework for four different types of private equity, showing that private equity buyouts were positively associated with creating new job opportunities in firms. In accordance with these findings, this study predicts that private equity and support have positive effects on ICTVs' economic performance and job opportunity creation:

H3 Private equity and support services are positively associated with ICTVs' economic performance.

H4 Private equity and support services are positively associated with job opportunities.

\section{Government support}

Government support is generally considered among the most important antecedents for firm success (McWilliams and Siegel 2001). Government financial and political support improves the financial stability and general condition of high-tech firms (Kang and Park 2012). Studies have investigated the role of government support, including public training and financial programs, in improving firm performance (Lerner 1996). Howe and Mcfetridge (1976) explored the effects of government support on the R\&D activities of Canadian companies to determine whether it improved their performance and efficiency. Several studies (e.g., Alchian and Demsetz
1972; Oakey 1983; Levy and Terleckyj 1983; Kim 2005) have revealed notable relationships between government support and the overall productivity of national economies. Favre et al. (2002) demonstrated that the French government's financial and political support promoted firms' R\&D activities as well as cooperation with other organizations (Favre et al. 2002). Dollar and Sokoloff (1990) found that the success and productivity of South Korean manufacturing companies were largely determined by government policies and support. Moreover, the World Bank (1993) identified government support as one of the most essential factors in the growth of companies in East Asia, South Korea, Japan, and Taiwan.

In addition, several studies have revealed positive relationships between national and local government support for companies and new employment opportunities (Klenow 1996; Lerner 1996). For example, Erickson and Friedman (1990) and Alvarez et al. (2009) showed that national government support promoted the creation of new jobs in several US states. Based on these consistent findings, this study proposes the following hypotheses on government support:

H5 Government support is positively associated with ICTVs' economic performance.

H6 Government support is positively associated with job opportunities.

\section{Research model}

Based on the posited hypotheses and causal relationships, the research model depicted in Fig. 1 below is proposed.

\section{Study design \\ Data collection}

This study used the 2012 Daejeon Regional Economic Reviving Survey conducted by Daejeon Technopark (a local government institute). The survey database contained information about companies located in the Daejeon metropolitan area since 2011, including their $R \& D$ activities, economic performance, number of employees, and current status. This study identified potential motivational antecedents through 10-min in-depth interviews with the managers of 20 ICTVs before administering the main survey. Using the interview results, this study determined the critical factors in ICTVs' economic performance (see Table 1). The main survey was sent to 300 venture companies drawn from the database. After excluding the companies that did not complete the survey, 213 companies remained as the final sample. 
Table 1 Results of in-depth interviews for identifying potential antecedents

\begin{tabular}{lll}
\hline & Factors & N (\%) \\
\hline 1 & Government support & $30(37.0 \%)$ \\
2 & Innovation effort & $22(27.2 \%)$ \\
3 & Private equity and support & $12(14.8 \%)$ \\
& services & \\
4 & Merger and acquisition & $7(8.6 \%)$ \\
5 & Product and service diversifica- & $4(4.9 \%)$ \\
& tion & $6(7.4 \%)$ \\
6 & Etc. & 81 responses from 20 managers $^{\text {a }}$ \\
\hline
\end{tabular}

${ }^{a}$ Multiple responses were allowed

\section{Measured variables}

The construct of innovation effort was measured with three items adopted from Evangelista et al. (2001). Private equity and support were measured with three items adopted from Dakhli and De Clercq (2004) and Luk et al. (2008). Government support was assessed with three items adopted from Cai et al. (2010). Economic performance was assessed with three items used in Henri and Journeault (2010) and Skiba et al. (2009). Job creation was measured with three items adopted from Lester (2005) and Kwon et al. (2015). A complete list of the questionnaire items used in this study appears in Table 2.

\section{Data analysis}

A confirmatory factor analysis (CFA) and structural equation modeling (SEM) using the LISREL 8.70 software were conducted to examine the validity of the measurement model and proposed research model, respectively. Research has found that SEM requires the minimum sample size to be larger than 200 for analytical validity (Fornell and Larcker 1981; Hair et al. 2006). The sample size of this study $(N=213)$ meets this criterion.

\section{Results}

Measurement model

As summarized in Table 3, the overall fit indices of the measurement model were satisfactory, except the ratio of the Chi square to the degrees of freedom $\left(\mathrm{x}^{2} / d f\right)$. Values for composite reliability and Cronbach's alpha were calculated to test the validity of each construct. Prior studies recommend that all factor loadings and composite reliability values exceed 0.50 and 0.70 , respectively (Anderson and Gerbing 1988; Hair et al. 2006). All correlations between constructs should be lower than the values of

\section{Table 2 Questionnaire items used in this study}

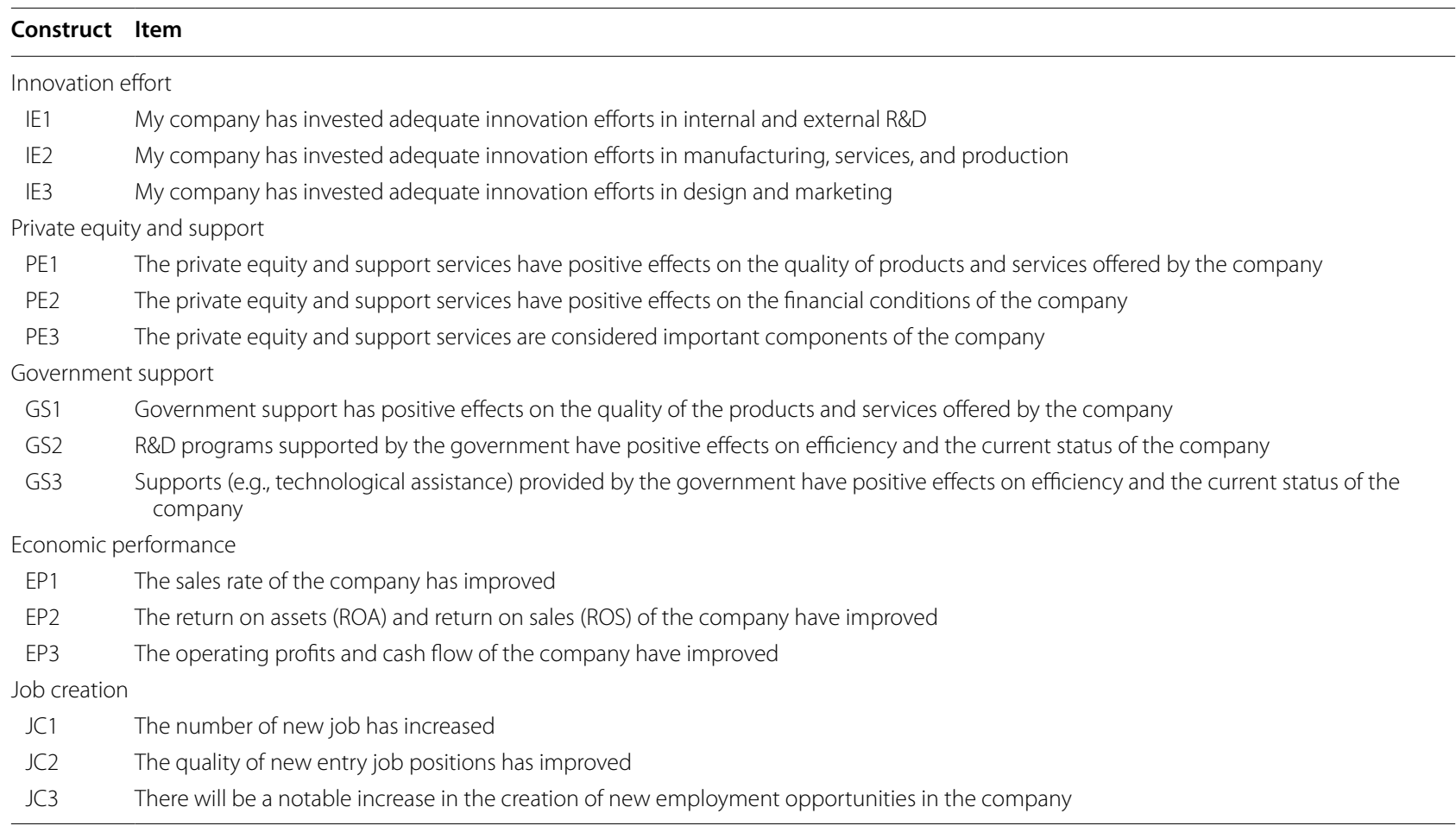


Table 3 The fit indices of the measurement model

\begin{tabular}{|c|c|c|c|}
\hline Fit indices & Values & $\begin{array}{l}\text { Recommended } \\
\text { level }\end{array}$ & Source \\
\hline$x^{2} / d f$ & $4.66(p<0.01)$ & $<3.0$ & Bagozzi and Yi (1988) \\
\hline $\mathrm{NFI}$ & 0.955 & $>0.900$ & $\begin{array}{l}\text { Bentler and Bonnett } \\
\text { (1980) }\end{array}$ \\
\hline$|F|$ & 0.911 & $>0.900$ & $\begin{array}{l}\text { Browne and Cudeck } \\
\text { (1993) }\end{array}$ \\
\hline $\mathrm{CFI}$ & 0.924 & $>0.900$ & $\begin{array}{l}\text { Fornell and Larcker } \\
\text { (1981) }\end{array}$ \\
\hline GFI & 0.912 & $>0.900$ & Hair et al. (2006) \\
\hline AGFI & 0.901 & $>0.900$ & Hoe (2008) \\
\hline SRMR & 0.040 & $<0.050$ & $\begin{array}{l}\text { Holbert and Stephen- } \\
\text { son (2002) }\end{array}$ \\
\hline RMSEA & 0.041 & $<0.050$ & $\begin{array}{l}\text { Jöreskog and Sörbom } \\
\text { (1996) }\end{array}$ \\
\hline
\end{tabular}

$N F I$ normed fit index, IFI incremental fit index, CFI comparative fit index, GFI goodness-of-fit index, $A G F I$ adjusted goodness-of-fit index, SRMR standardized root mean square residual, $R M S E A$ root mean square error of approximation

the square root of the average variance extracted (Fornell and Larcker 1981). This study's measurement model satisfied all these standards (see Tables 4, 5).

\section{Hypotheses testing}

The hypotheses were tested by validating the structural model. The SEM results indicated that the overall fit indices of the proposed research model were satisfactory, except $\chi^{2} / d f$ (see Table 6).

As Fig. 2 and Table 7 show, all hypotheses were supported except H4. The economic performance of ICTVs
Table 5 Results of discriminant validity; diagonal elements are the square root-values of the average variance extracted

\begin{tabular}{llllll}
\hline Construct & $\mathbf{1}$ & $\mathbf{2}$ & $\mathbf{3}$ & $\mathbf{4}$ & $\mathbf{5}$ \\
\hline $\begin{array}{l}\text { 1. Innovation effort } \\
\begin{array}{l}\text { 2. Private equity and support } \\
\text { services }\end{array}\end{array}$ & 0.891 & & & & \\
3. Government support & 0.108 & 0.892 & & & \\
$\begin{array}{l}\text { 4. Economic performance } \\
\text { 5. Job creation }\end{array}$ & 0.229 & 0.185 & 0.828 & & \\
& 0.388 & 0.079 & 0.402 & 0.856 & \\
& 0.321 & 0.255 & 0.391 & 0.224 & 0.869
\end{tabular}

was determined by government support $(\mathrm{H} 5, \beta=0.329$, $p<0.001)$, innovation effort $(\mathrm{H} 1, \beta=0.243, p<0.001)$, and private equity and support $(\mathrm{H} 3, \beta=0.144, p<0.05)$. New job opportunities were influenced by two factorsgovernment support $(\mathrm{H} 6, \beta=0.284, p<0.001)$ and innovation effort $(\mathrm{H} 2, \beta=0.225, p<0.01)$. However, private equity and support did not have a significant effect on job creation (H4, $p>0.05) ; 24.2 \%$ of the variance in job creation was explained by innovation effort and government support, while government support, innovation effort, and private equity and support explained $28.8 \%$ of the variance in ICTVs' economic performance.

\section{Discussion}

This study proposed and validated an integrated research model for economic performance and job creation to examine the role of innovation effort, private equity and support, and government support in enhancing ICTVs'

Table 4 Internal validity and convergent reliability of the constructs

\begin{tabular}{|c|c|c|c|c|c|c|}
\hline \multirow[t]{2}{*}{ Construct } & \multirow[t]{2}{*}{ Item } & \multicolumn{2}{|l|}{ Internal validity } & \multicolumn{3}{|c|}{ Convergent reliability } \\
\hline & & Cronbach's alpha & Item-total correlation & Factor loadings & Composite reliability & $\begin{array}{l}\text { Average variance } \\
\text { extracted }\end{array}$ \\
\hline \multirow[t]{3}{*}{ Innovation effort } & IE1 & 0.869 & 0.778 & 0.914 & 0.921 & 0.794 \\
\hline & IE2 & & 0.847 & 0.871 & & \\
\hline & IE3 & & 0.822 & 0.889 & & \\
\hline \multirow{3}{*}{$\begin{array}{l}\text { Private equity and } \\
\text { support services }\end{array}$} & PE1 & 0.871 & 0.812 & 0.896 & 0.921 & 0.795 \\
\hline & PE2 & & 0.806 & 0.899 & & \\
\hline & PE3 & & 0.836 & 0.880 & & \\
\hline \multirow[t]{3}{*}{ Government support } & GS1 & 0.770 & 0.663 & 0.845 & 0.868 & 0.686 \\
\hline & GS2 & & 0.732 & 0.802 & & \\
\hline & GS3 & & 0.676 & 0.837 & & \\
\hline \multirow[t]{3}{*}{ Economic performance } & EP1 & 0.817 & 0.844 & 0.786 & 0.891 & 0.733 \\
\hline & $\mathrm{EP} 2$ & & 0.709 & 0.881 & & \\
\hline & EP3 & & 0.675 & 0.897 & & \\
\hline \multirow[t]{3}{*}{ Job creation } & $\mathrm{JC1}$ & 0.838 & 0.751 & 0.884 & 0.903 & 0.756 \\
\hline & $J C 2$ & & 0.758 & 0.879 & & \\
\hline & $\mathrm{JC} 3$ & & 0.813 & 0.845 & & \\
\hline
\end{tabular}


Table 6 The fit indices of the research model

\begin{tabular}{|c|c|c|c|}
\hline Fit indices & Values & $\begin{array}{l}\text { Recommended } \\
\text { level }\end{array}$ & Source \\
\hline$x^{2} / d f$ & $4.97(p<0.01)$ & $<3.0$ & Bagozzi and Yi (1988) \\
\hline NFI & 0.936 & $>0.900$ & $\begin{array}{l}\text { Bentler and Bonnett } \\
\text { (1980) }\end{array}$ \\
\hline$|F|$ & 0.901 & $>0.900$ & $\begin{array}{l}\text { Browne and Cudeck } \\
\text { (1993) }\end{array}$ \\
\hline CFI & 0.919 & $>0.900$ & $\begin{array}{l}\text { Fornell and Larcker } \\
\text { (1981) }\end{array}$ \\
\hline GFI & 0.921 & $>0.900$ & Hair et al. (2006) \\
\hline AGFI & 0.925 & $>0.900$ & Hoe (2008) \\
\hline SRMR & 0.048 & $<0.050$ & $\begin{array}{l}\text { Holbert and Stephen- } \\
\text { son (2002) }\end{array}$ \\
\hline RMSEA & 0.047 & $<0.050$ & $\begin{array}{l}\text { Jöreskog and Sörbom } \\
\text { (1996) }\end{array}$ \\
\hline
\end{tabular}

$N F I$ normed fit index, IFI incremental fit index, CFI comparative fit index, GFI goodness-of-fit index, $A G F I$ adjusted goodness-of-fit index, SRMR standardized root mean square residual, RMSEA root mean square error of approximation

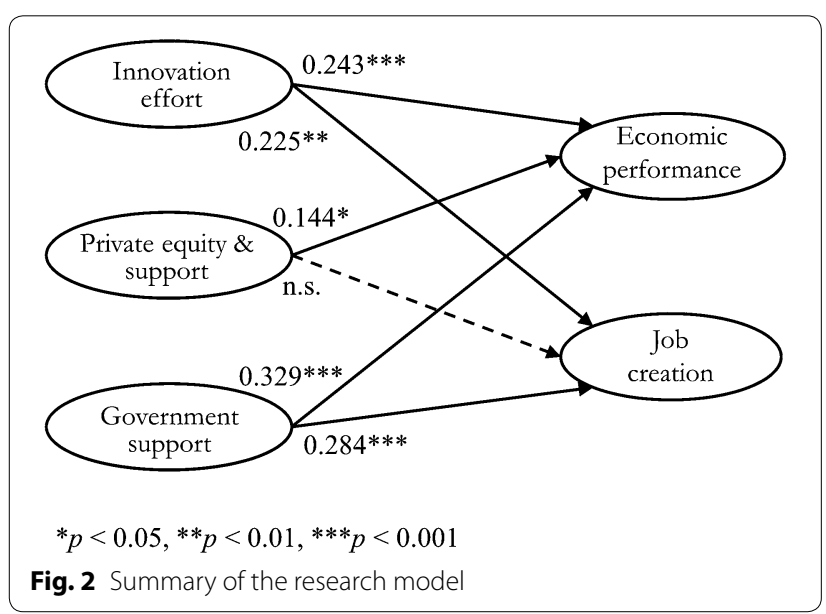

economic performance and capacity to offer jobs. Our findings suggest that innovation effort and government support are the most efficient motivational factors in the successful growth of ICTVs, thus rejecting the null hypotheses.
These results of our SEM analysis provide several noteworthy implications for researchers and practitioners. This study offers a systematic and comprehensive understanding of a structural concept concerning three motivations for and two outputs of the economic performance and job creation of ICTVs in DDI. The SEM results confirm that innovation effort is not the only important factor in increasing firms' economic performance but that both government support and private equity and support are also significant determinants of ICTVs' economic performance. Innovation effort and government support are also revealed as key determinants of job creation.

Second, our findings provide meaningful insights into ways of facilitating the plans and operations of South Korean ICTVs. The South Korean economy is heavily reliant on manufacturing, and much of the government's support is devoted to promoting the infrastructure and hardware aspects of innovation clusters.

\section{Conclusions}

The current study explores the core motivations in improving economic performance for ICTVs in South Korea. Based on the structural results from the data of more than 200 ICTVs, several key points can be presented.

Based on the findings, the current study provides several insights for South Korean ICT industry. The Korean government should aim to provide carefully planned political, financial, and physical assistance to bolster the software aspects of innovation, such as human resources, finance, and R\&D collaboration (Park et al. 2014). Specifically, Table 8 shows the recommendations for the Korean government which should place greater emphasis.

The relatively weak effects of private equity and support might have been produced by circumstances specific to South Korea's ICT industry. Private equity and support are uncommon in South Korea, and less social capital and support are available than government support; thus, most ICTVs may not require the benefit of social capital and support. This suggests that the Korean government should expand its support by providing the equivalent of private equity and support.

Table 7 Results of the hypothesis tests

\begin{tabular}{|c|c|c|c|c|}
\hline Hypothesis & Path coefficient & Standard error & Critical ratio & Supported \\
\hline H1. Innovation effort $\rightarrow$ Economic performance & $0.243^{* * *}$ & 0.062 & 3.408 & Yes \\
\hline H2. Innovation effort $\rightarrow$ Job creation & $0.225^{* *}$ & 0.089 & 3.214 & Yes \\
\hline H3. Private equity and support services $\rightarrow$ Economic performance & $0.144^{*}$ & 0.057 & 1.917 & Yes \\
\hline H4. Private equity and support services $\rightarrow$ Job creation & 0.096 & 0.082 & 1.309 & No \\
\hline H5. Government support $\rightarrow$ Economic performance & $0.329^{* * *}$ & 0.074 & 3.991 & Yes \\
\hline H6. Government support $\rightarrow$ Job creation & $0.284^{* * *}$ & 0.052 & 4.495 & Yes \\
\hline
\end{tabular}

*** $p<0.001 ;{ }^{* *} p<0.01 ;{ }^{*} p<0.05$ 


\section{Table 8 Recommendations for the Korean government}

\begin{tabular}{ll}
\hline Order & Content \\
\hline 1 & $\begin{array}{l}\text { Integrating the nation's support systems } \\
\text { Integrating government departments and agencies to increase } \\
\text { communication efficiency }\end{array}$ \\
3 & $\begin{array}{l}\text { Investing in R\&D and human resources rather than providing } \\
\text { direct financial support }\end{array}$ \\
4 & Strategic planning for ICTV-specific support policies \\
5 & Providing prompt administrative assistance \\
6 & Providing appropriate tax support \\
7 & Designing effective curricula for IT personnel training \\
8 & Expanding collaboration between industry and academia \\
9 & Employing experienced retirees \\
10 & Establishing collaborative research facilities \\
11 & Developing region-specific facilities and services \\
\hline
\end{tabular}

This study has several limitations. First, generalizing our findings to other regions or countries is difficult because our sample is restricted to ICTVs in one area of South Korea. Second, several unexamined factors might have affected the proposed causal relationships in the research model. Studies have found that cultural and organizational factors (Casson 1993; Hansen and Warnerfelt 1989) and environmental disclosure (AlTuwaijri et al. 2004) have significant effects on firms' economic performance. Additionally, while the global ICT industry typically specializes in both hardware and software, ICTVs in South Korea focuses primarily on the hardware sector of the ICT industry, thereby restricting the generalizability of our findings. By addressing these limitations, future studies may develop a more comprehensive model for predicting the economic performance of ICTVs at the international level.

\section{Authors' contributions \\ EP and SJK wrote the majority of the manuscript. KJK and JYO revised and corrected the manuscript. APdP and KY contributed to the data acquisi- tion, analysis and interpretations. All authors read and approved the final manuscript.}

\section{Author details \\ 1 Korea Institute of Civil Engineering and Building Technology (KICT), Goyang, Republic of Korea. ${ }^{2}$ Department of Media and Communication, City University of Hong Kong, Kowloon, Hong Kong. ${ }^{3}$ Department of Business Administra- tion, Dongguk University, Gyeongju, Republic of Korea. ${ }^{4}$ Korea Advanced Institute of Science and Technology (KAIST), N5 2111, KAIST College Building 2 291 Daehak-ro, Yuseong-gu, Daejeon 34141, Republic of Korea. ${ }^{5}$ Department of Interaction Science, Sungkyunkwan University, Seoul, Republic of Korea. ${ }^{6}$ University Jaume-I, Castellón, Spain. ${ }^{7}$ Daejeon Technopark, Daejeon, Repub- lic of Korea.}

\section{Acknowledgements}

This work was supported by the National Research Foundation of Korea Grant funded by the Korean Government (NRF-2014S1 A5A2A01011769). This study was also supported by the Dongguk University Research Fund of 2015.

\section{Competing interests}

The authors declare that they have no competing interests.

Received: 5 October 2015 Accepted: 29 June 2016

Published online: 11 July 2016

References

Alchian AA, Demsetz H (1972) Production, information costs, and economic organization. Am Econ Rev 62:777-795

Al-Tuwaijri S, Christensen E, Hughes KE II (2004) The relations among environmental disclosure, environmental performance, and economic performance: a simultaneous equations approach. Account Organ Soc 29:447-472

Alvarez R, Ortega CB, Navarro L (2009) The effect of product mix changes on productivity among chilean manufacturing plants. Retrieved 14 Jan 2014, from http://www.merit.unu.edu/MEIDE/papers/2010/Alvarez_Ortega_ Navarro.pdf

Amara N, Landry R (2005) Sources of information as determinants of novelty of innovation in manufacturing firms: evidence from the 1999 statistics Canada innovation survey. Technovation 25:245-259

Anderson JC, Gerbing DW (1988) Structural equation modeling in practice: a review and recommended two-step approach. Psychol Bull 103:411-423

Bacon N, Wright M, Ball R, Meuleman M (2013) Private equity, HRM, and employment. Acad Manag Perspect 27:7-21

Bagozzi RP, Yi Y (1988) On the evaluation of structural equation models. J Acad Mark Sci 16:74-94

Becker W, Dietz J (2004) R\&D co-operation and innovation activities of firms-evidence for the German manufacturing industry. Res Policy 33:209-223

Bentler PM, Bonnett DG (1980) Significance tests and goodness of fit in the analysis of covariance structures. Psychol Bull 88:588-606

Bogliacino F, Pianta M (2010) Innovation and employment: a reinvestigation using revised Pavitt classes. Res Policy 39:799-809

Boscherini L, Chiaroni D, Chiesa V, Frattini F (2012) How to integrate open and closed innovation. Int J Entrep Innov Manag 16:226-244

Browne MW, Cudeck R (1993) Alternative ways of assessing model fit. In: Bollen KA, Long JS (eds) Testing structural equation models. Sage, Newbury Park, pp 136-162

Cai S, Jun M, Yang Z (2010) Implementing supply chain information integration in China: the role of institutional forces and trust. J Oper Manag 28:257-268

Cainelli G, Evangelista R, Savona M (2004) The impact of innovation on economic performance in services. Serv Ind J 24:116-130

Cainelli G, Evangelista R, Savona M (2006) Innovation and economic performance in services: a firm-level analysis. Camb J Econ 30:435-458

Caloghirou Y, Kastelli I, Tsakanikas A (2004) Internal capabilities and external knowledge sources: complements or substitutes for innovative performance? Technovation 24:29-39

Casson M (1993) Cultural determinants of economic performance. J Comp Econ 17:418-442

Chesbrough H (2003) The era of open innovation. Sloan Manag Rev 44:35-41

Chesbrough $\mathrm{H}$ (2006) Open innovation: a new paradigm for understanding industrial innovation. In: Chesbrough $\mathrm{H}$, Vanhaverbeke W, West J (eds) Open innovation: researching a new paradigm. Oxford University Press, Oxford, pp 1-12

Cornelli F, Karakas O (2008) Private equity and corporate governance: do LBOs have more effective boards? Retrieved 3 March 2014, from http://www. ecgi.org/competitions/rof/files/Do\%20LBOs\%20have\%20more\%20effective\%20boards,\%20(Cornelli,\%20Karakas).pdf

Cotter JF, Peck SW (2001) The structure of debt and active equity investors: the case of the buyout specialist. J Financ Econ 59:101-147

Dakhli M, De Clercq D (2004) Human capital, social capital, and innovation: a multi-country study. Entrepr Reg Dev Int J 16:107-128

Dollar D, Sokoloff K (1990) Patterns of productivity growth in South Korean manufacturing industries, 1963-1979. J Dev Econ 33:309-327 
Erickson RA, Friedman SW (1990) Enterprise zones: 1. Investment and job creation of state government programs in the United States of America. Environ Plan C Gov Policy 8:251-267

Evangelista R, lammarino S, Mastrostefano V, Silvani A (2001) Measuring the regional dimension of innovation. Lessons from the Italian Innovation Survey. Technovation 21:733-745

Favre F, Syoum N, Etienne P (2002) The effect of spillovers and government subsidies on R\&D, international R\&D cooperation and profits: evidence from France. Retrieved 3 March 2014, from http://www.econbiz.de/ Record/the-effect-of-spillovers-and-government-subsidies-on-r-dinternational-r-d-cooperation-and-profits-evidence-from-france-favreflorent/10001639447

Fornell C, Larcker DF (1981) Evaluating structural equation models with unobservable variables and measurement error. J Mark Res 18:39-50

Guo S, Hotchkiss E, Song W (2011) Do buyouts (still) create value? J Finance 66:479-517

Hair JF, Black WC, Babin BJ, Anderson RE (2006) Multivariate data analysis. Prentice Hall, Upper Saddle River

Hall BH, Lotti F, Mairesse J (2008) Employment, innovation, and productivity: evidence from Italian microdata. Ind Corp Change 17:813-839

Hansen GS, Warnerfelt B (1989) Determinants of firm performance: the relative importance of economic and organizational factors. Strateg Manag J 10:399-411

Henri J, Journeault M (2010) Eco-control: the influence of management control systems on environmental and economic performance. Account Organ Soc 35:63-80

Herzog P (2011) Open and closed innovation: different cultures for different strategies. Gabler, Wiesbaden

Herzog P, Leker J (2010) Open and closed innovation — different innovation cultures for different strategies. Int J Technol Manag 52:322-343

Hoe SL (2008) Issues and procedures in adopting structural equation modeling technique. J Appl Quant Methods 3:76-83

Holbert RL, Stephenson MT (2002) Structural equation modeling in the communication sciences, 1995-2000. Hum Commun Res 28:531-551

Howe JD, McFetridge DG (1976) The determinants of R\&D expenditures. Can J Econ 9:57-71

Jöreskog KG, Sörbom D (1996) LISREL 8: user's reference guide. Scientific Software International, Chicago

Jung H, Mah JS (2014) The role of the Government in Science and Technology Education of Korea. Sci Technol Soc 19:199-227

Kang KH, Kang J (2009) How do firms source external knowledge for innovation? Analysing effects of different knowledge sourcing methods. Int J Innov Manag 13:1-17

Kang K, Park H (2012) Influence of government R\&D support and inter-firm collaborations on innovation in Korean biotechnology SMEs. Technovation 32:68-78

Kim L (1999) Building technological capability for industrialization: analytical frameworks and Korea's experience. Ind Corp Change 8:111-136

Kim Y (2005) The effects of technological collaborations on the innovation outputs and corporate financial performance in small and medium-sized firms of Busan city. Korean Small Bus Rev 27:123-154

Kim S, An G (2012) A comparison of Daedeok Innopolis cluster with the San Diego biotechnology cluster. World Technopolis Rev 1:118-128

Kim H, Park Y (2010) The effects of open innovation activity on performance of SMEs: the case of Korea. Int J Technol Manag 52:236-256

Klenow PJ (1996) Industry innovation: where and why. In: Carnegie-Rochester conference series on public policy, vol 44, pp 125-150

Kwon SJ, Park E, Ohm JY, Yoo K (2015) Innovation activities and the creation of new employment: an empirical assessment of South Korea's manufacturing industry. Soc Sci Inform 54:354-368

Lee S, Park G, Yoon B, Park J (2010) Open innovation in SMEs-an intermediated network model. Res Policy 39:290-300

Lerner J (1996) The government as venture capitalist: the long-run effects of the SBIR program. Retrieved 3 March 2014, from http://www.nber.org/ papers/w5753
Lester NN (2005). Assessing economic development incentives: central texas city manager perspectives. Retrieved 3 March 2014, from https://digital. library.txstate.edu/handle/10877/3668

Levy DM, Terleckyj NE (1983) Effects of government R\&D on private R\&D investment and productivity: a macroeconomic analysis. Bell J Econ 14:551-561

Löfsten H, Lindelöf P (2005) R\&D networks and product innovation pattersacademic and non-academic new technology-based firms on Science Parks. Technovation 25:1025-1037

Luk C, Yau OHM, Sin LYM, Tse ACB, Chow RPM, Lee JSY (2008) The effects of social capital and organizational innovativeness in different institutional contexts. J Int Bus Stud 39:589-612

McWilliams A, Siegel D (2001) Corporate social responsibility: a theory of the firm perspective. Acad Manag Rev 26:117-127

Oakey RP (1983) New technology, government policy and regional manufacturing employment. Area 15:61-65

Pahlavani M, Harvie C (2008) Multiple structural breaks in Korea's macroeconomic data: an application of the Lumsdaine and Papell test. J Korean Econ 9:425-441

Park H, Kang K, Kim HR (2011) Development of biotechnology clusters: the case of Daedeok Science Town, Korea. Asian J Technol Innov 19:201-218

Park E, Kwon SJ, Kim H, Ohm J, Chang HJ (2014) What is the Right R\&D Strategy for Overcoming the Difficulties of the South Korean IT Industry?. Inf Technol Dev 20:339-352

Schumpeter J (1961) The theory of economic development. Harvard University Press, Cambridge

Sengupta JK, Espana JR (1994) Exports and economic growth in Asian NICs: an econometric analysis for Korea. Appl Econ 26:41-51

Shan W, Walker G, Kogut B (1994) Interfirm cooperation and startup innovation in the biotechnology industry. Strateg Manag J 15:387-394

Shin D, Hassink R (2011) Cluster life cycles: the case of the shipbuilding industry cluster in South Korea. Reg Stud 45:1387-1402

Skiba M, Smith DR, Marshall KP (2009) Applying Merton's theory of anomia to career disruptions. Manag Res News 32:392-404

Souitaris V (2002) Firm-specific competencies determining technological innovation: a survey in Greece. R\&D Manag 32:61-77

Wong PK, Ho YP, Autio E (2005) Entrepreneurship, innovation and economic growth: evidence from GEM data. Small Bus Econ 24:335-350

World Bank (1993) Sustaining rapid development in East Asia and the Pacific. World Bank, Washington, DC

Wood G, Wright M (2010) Private equity and human resource management: an emerging agenda. Hum Relat 63:1279-1296

Wright M, Hoskisson R, Busenitz L, Dial J (2000) Entrepreneurial growth through privatization: the upside of management buy-outs. Acad Manag Rev 25:591-601

Wright M, Hoskisson R, Busenitz L (2001) Firm rebirth: buy-outs as facilitators of strategic growth and entrepreneurship. Acad Manag Exec 15:111-125

Wright M, Gilligan J, Amess K (2009) The economic impact of private equity: what we know and what we would like to know. Venture Cap 11:1-21

Yun S, Lee J (2013) An innovation network analysis of science clusters in South Korea and Taiwan. Asian J Technol Innov 21:277-289

\section{Submit your manuscript to a SpringerOpen ${ }^{\circ}$ journal and benefit from:}

- Convenient online submission

- Rigorous peer review

- Immediate publication on acceptance

- Open access: articles freely available online

- High visibility within the field

- Retaining the copyright to your article

Submit your next manuscript at springeropen.com 